удК $347.97 / 99$

DOI https://doi.org/10.32837/apdp.v0i88.3068

А. В. Сухарко

\title{
СИСТЕМА ОРГАНІВ СУДДІВСЬКОГО ВРЯДУВАННЯ В УКРАЇНІ
}

Постановка проблеми. У Законі України «Про судоустрій і статус суддів» (далі Закон) [1] було запропоновано до реалізації на практиці новий термін - «суддівське врядування». На жаль, визначення Законом зазначеного терміна не надається, загалом він уживається в тексті Закону лише тричі. Водночас $є$ більш зрозумілий та звичний для використання термін «суддівське самоврядування», який залишився та вживається в Законі. Розмежування зазначених інститутів та визначення оптимальної структури системи органів суддівського врядування потребують свого наукового дослідження й обгрунтування.

Аналіз останніх досліджень і публікацій. Питання дослідження суддівського самоврядування та діяльності Вищої ради правосуддя та Вищої кваліфікаційної комісії суддів України висвітлювали такі дослідники й фахівці, як: Р.О. Куйбіда, І.В. Назаров, С.Г. Штогун, О.В. Курганський, О.Д. Гуменний, К.Ф. Гуценко, P.В. Ігонін, Р.І. Кирилюк, Ю.О. Косткіна, О.В. Курганський, І.Є. Марочкін, Д.В. Приймаченко, Н.В. Сібільова, А.А. Стрижак, О.М. Тарасишина, Н.С. Юзікова й інші.

Метою статті $є$ аналіз нормативного врегулювання поняття та системи органів суддівського врядування, визначення їхніх завдань та компетенції, розмежування з органами суддівського самоврядування, формулювання обгрунтованих пропозиції щодо подальшого вдосконалення їхньої діяльності.

Виклад основного матеріалу дослідження. У науковому юридичному середовищі вже звернули увагу на проблематику врегулювання інституту суддівського врядування. Так, наприклад, О.А. Боровицький уважає, що за умов загального призначенні у виді забезпечення незалежності судової влади та суддів цільовим призначенням «суддівського врядування» $€$ створення та забезпечення для органів судової влади таких організаційних умов, за яких діяльність суду буде прозорою, правосуддя - справедливим, неупередженим, а судді відповідатимуть високим вимогам професійної підготовки, етики та доброчесності. Завданням суддівського самоврядування $€$ захист професійних прав суддів та вирішення питань внутрішньої діяльності судів. Водночас автор підкреслює, що за міжнародними та європейськими стандартами органи, яким довірено захищати незалежність суддів, повинні становити автономні, незалежні органи судової влади, що забезпечуе можливість виконання індивідуальними суддями своїх функцій, незалежно від будь-якого контролю з боку виконавчої і законодавчої влади та без неправомірного тиску зсередини судової системи [2, с. 375$]$.

О.В. Курганський підкреслюе, що цільовим призначенням суддівського врядування $є$ створення та забезпечення для органів судової влади таких умов функціонування, за яких діяльність суду буде прозорою, правосуддя - справедливим 
та відповідним нормам Конституції України і законам, а судді як людський субстрат судової влади - відповідатимуть високим вимогам професійної підготовки та доброчесності [3, с. 152].

Що стосується законодавчого регулювання зазначеної проблематики, то у ст. 92 Закону зазначається, що Вища кваліфікаційна комісія суддів України (далі - ВККСУ) є державним органом суддівського врядування, який на постійній основі діє в системі правосуддя України. У подальшому уточняється статус ВККСУ і зазначається, що вона є юридичною особою, має печатку із зображенням державного герба України та своїм найменуванням, самостійний баланс та рахунки в органах Державної казначейської служби України (ч. 2 ст. 92).

У ст. 147 «Система забезпечення функціонування судової влади» є така норма: «В Україні діє єдина система забезпечення функціонування судової влади - судів, органів суддівського врядування, інших державних органів та установ системи правосуддя». У ст. 48 Закону «Незалежність судді» однією з гарантій забезпечення незалежності суддів закріплено таке: «9) функціонуванням органів суддівського врядування та самоврядування» .

Також термін «суддівське врядування» уживається в Законі України «Про Вищу раду правосуддя» [4]. Так, у ст. 1 зазначеного Закону надається визначення Вищої ради правосуддя, відповідно до якого вона є колегіальним, незалежним конституційним органом державної влади та суддівського врядування, який діє в Україні на постійній основі для забезпечення незалежності судової влади, її функціонування на засадах відповідальності, підзвітності перед суспільством, формування доброчесного та високопрофесійного корпусу суддів, додержання норм Конституції і законів України, а також професійної етики в діяльності суддів і прокурорів. Також у нормі доповнюється, що Вища рада правосуддя є юридичною особою, видатки на її утримання визначаються окремим рядком у державному бюджеті України (ч. 2 ст. 1).

Отже, ми можемо дійти висновку, що національним законодавством України передбачено функціонування двох органів суддівського врядування: Вищої кваліфікаційної комісії суддів України та Вищої ради правосуддя. 3 огляду на той факт, що вони мають приблизно однаковий статус, ми можемо виділити характерні ознаки органу суддівського врядування, а саме::

а) це державний орган, статус якого визначається Конституцією України або законом;

б) має статус юридичної особи і фінансується з державного бюджету;

в) працює на постійній основі;

г) є колегіальним, незалежним органом у системі правосуддя;

г) до складу входять не лише професійні судді, а й представники інших правничих професій;

д) відповідальний за забезпечення незалежності суддів, високопрофесійного складу суддівського корпусу.

У процесі надання характеристики органів суддівського врядування необхідно звернути увагу на завдання, що на них покладаються, порядок формування та повноваження, особливості взаємодії з іншими органами системи забезпечення функціонування судової влади. 
На наш погляд, передусім варто звернути увагу на відмінності між органами суддівського врядування та суддівського самоврядування.

Відповідно до ч. 5 ст. 6 Закону, суддівське самоврядування створюється і діє з метою захисту професійних інтересів суддів та вирішення питань внутрішньої діяльності судів. До речі, у подальшому вирішення питань внутрішньої діяльності судів органами суддівського самоврядування Закон розглядає як один з елементів, що забезпечує єдність системи судоустрою (п. 8 ч. 4 ст. 17). Також функціонування органів суддівського самоврядування Законом оцінюється як гарантія забезпечення незалежності суддів (п. 9 ч. 5 ст. 48 ).

Поняття, завдання організаційні форми та повноваження органів суддівського самоврядування конкретизуються окремим розд. VIII Закону. Наприклад, суддівське самоврядування визначається як самостійне колективне вирішення суддями питань захисту професійних інтересів суддів та внутрішньої діяльності судів в Україні (ч. 1 ст. 126). Додається, що суддівське самоврядування є не лише гарантією забезпечення незалежності суддів, а й сприяє створенню належних організаційних та інших умов для забезпечення нормальної діяльності судів і суддів, утвердженню незалежності суду, забезпеченню захисту суддів від втручання в їхню діяльність, а також підвищенню рівня роботи з кадрами в системі судів.

Що стосується питань внутрішньої діяльності судів, то до таких Законом віднесено питання організаційного забезпечення судів та діяльності суддів, соціального захисту суддів та їхніх сімей, а також інші питання, що безпосередньо не пов'язані зі здійсненням правосуддя (ч. 3 ст. 126). Таке визначення суддівського самоврядування I.В. Назаров охарактеризував як «небезпечне», оскільки воно звужує межі цієї діяльності до «внутрішньої діяльності судів», тим самим обмежує незалежність судової влади в Україні. Проте судове самоврядування аж ніяк не є питанням внутрішньої діяльності судів [5, с. 84].

Завданням суддівського самоврядування визначено вирішення питань щодо:

- забезпечення організаційної єдності функціонування органів судової влади;

- зміцнення незалежності судів, суддів, захисту професійних інтересів суддів, зокрема й захисту від втручання в їхню діяльність;

- участі у визначенні потреб кадрового, фінансового, матеріально-технічного й іншого забезпечення судів, контроль за додержанням установлених нормативів такого забезпечення;

- обрання суддів на адміністративні посади в судах у порядку, встановленому цим Законом;

- призначення суддів Конституційного Суду України;

- обрання суддів до складу Вищої ради правосуддя в порядку, установленому законом.

Що стосується переліку органів суддівського самоврядування, він є значно ширше порівняно з органами суддівського врядування і складається зі зборів суддів кожного суду, Пленуму Верховного Суду, Ради суддів України та з’їзду суддів України.

З аналізу поняття, завдань і організаційних форм суддівського самоврядування можна виділити такі відмінності даного інституту від суддівського врядування: 
- до їхнього складу входять виключно судді, ідеться саме про діючих суддів;

- поряд із завданням захисту незалежності суддів є завдання захисту професійних інтересів суддів, що виходить за межі і відрізняється від поняття незалежності;

- дуже часто робота суддівського самоврядування характеризується як участь у вирішенні питання, а не вирішення питання, тобто здебільшого суддівське самоврядування - це обов'язковий елемент ухвалення рішення, але не суб'єкт його ухвалення.

Таке порівняння надає можливість дійти висновку, що одночасне функціонування суддівського врядування та суддівського самоврядування цілком обгрунтоване. Обидві системи мають можливість співпрацювати разом у найбільш важливих напрямах - забезпечення незалежності суддів та судів, консолідувати свої зусилля. Водночас мають чітко визначену власну компетенцію, яка відповідає особливостям порядку їх формування, складу, завданням та меті створення.

Так само в межах розгляду проблематики системи органів суддівського врядування необхідно враховувати останні тенденції в реформуванні органів судової гілки влади. Їхня особливість полягає у прискоренні процесів формування нових вищих судів, оптимізації структури судоустрою України, оцінці результатів кваліфікаційного оцінювання суддів і ефективності зазначених процесів.

Часто ми можемо почути думку про можливість об’єднання органів суддівського врядування, особливо в умовах фактичної відсутності ВККСУ. Якщо оцінювати таку можливість, варто звернути увагу на такі аспекти:

1. Позитивним моментом такого рішення можестати визначення єдиного органу, відповідального за якість суддівського корпусу і забезпечення незалежності суддів. Це сприятиме оптимізації процесу визначення найкращих кандидатів на суддівські посади, визначення суддів, які не справляються з виконанням своїх обов'язків, а також зменшенню витрат держави на забезпечення відповідного процесу.

2. Незважаючи на суттєві зміни і корегування в нормативному забезпеченні діяльності органів суддівського врядування, розподіл повноважень між ВККСУ та ВРП багато в чому є штучним [6, с. 65] і не підтверджує тезу про те, що функціонування двох самостійних і подібних органів для вирішення того кола питань, що входять до їхньої юрисдикції, є оптимальним, потрібним і ефективним. Дотепер актуальним залишається питання: чому ВККСУ визначає найкращі кандидатури для зайняття суддівських посад, а подання Президенту України про їх призначення на посаду вносить ВРП, якщо їі участь у цьому процесі мінімальна? $€$ й інші питання, які свідчать про те, що така модель не є оптимальною і може бути визнана лише як перехідна. Тому залишення одного із двох органів може стати природнім рішенням, що завершить цей «перехідний» період.

Водночас існує значна кількість аргументів про те, що в українських реаліях сформована ситуація, коли аргументи про недоцільність функціонування двох органів суддівського врядування вже не настільки безапеляційні. Наприклад, порядок формування складу ВККСУ цілком відповідав міжнародним стандартам і рекомендаціям Ради Європи (більшість складу обиралась суддями із числа суддів або суддів у відставці). По-друге, порядок формування іiі складу був менше заполітизований порівняно із ВРП, оскільки Верховна Рада України і Президент Укра- 
їни не брали участі в її формуванні. По-трете, ВККСУ виконує майже всі обов'язки, що покладаються на відповідні органи в інших європейських країнах (підготовка кандидатів на посаду судді, проведення відбору найкращих для призначення на посади, організація процесу підвищення кваліфікації суддів, прогнозування потреб підготовки суддівських кадрів тощо).

Так само до недоліків моделі об'єднання органів суддівського врядування необхідно віднести пов'язану із цим потребу суттєвих змін у Конституції України. На цей час повноваження і завдання між ВРП і ВККСУ чітко нормативно розділені, можна сказати, що їх сукупний перелік якраз визначає суть суддівського врядування в Україні. Відповідно, якщо ставити питання про об'єднання зазначених органів, виникне потреба суттєвого корегування законодавства на рівні Основного закону країни. У сучасних реаліях це не виглядає проблемою, але менш складним завдання від цього не стає.

Вирішення зазначеної проблематики погіршується невизначеністю подальшої долі ВККСУ, недостатністю законодавчого регулювання її діяльності та відсутністю фізично сформованого та діючого складу. Майже річна перерва в роботі ВККСУ призвела до накопичення значної кількості невирішених справ, що робить просто неможливим об’єднання двох органів суддівського врядування за таких обставин із причин прогнозовано очевидної неможливості їх швидкого розгляду одним новоствореним органом.

Висновки. У будь-якому разі під час вирішення подальшої долі системи органів суддівського врядування України необхідно дотримуватися певних умов і правил.

По-перше, існує низка міжнародних стандартів у зазначеній сфері, яких Україна дотримується останні кілька десятиліть і які не можна порушувати й у подальшому. Такі стандарти містяться в: (а) Основних принципах незалежності судових органів, схвалених резолюціями 40/32 і 40/146 Генеральної Асамблеї ООН від 29 листопада і 13 грудня 1985 р.; (б) рекомендаціях щодо ефективного впровадження Основних принципів незалежності судових органів (ухвалені резолюцією Економічної та Соціальної Ради ООН 1989/60 та схвалені резолюцією Генеральної Асамблеї ООН 44/162 від 15 грудня 1989 р.); (в) рекомендаціях CM/Rec (2010) 12 Комітету міністрів Ради Європи державам-членам щодо суддів: незалежність, ефективність та обов'язки від 17 листопада 2010 р.; (г) Бангалорських принципах поведінки суддів (ухвалені резолюцією 2006/23 Економічної та Соціальної Ради ООН від 27 липня 2006 р.); (ґ) Європейській хартії про Закон «Про статус суддів» від 10 липня 1998 р.; (д) спільному висновку Венеціанської комісії й Директорату з прав людини та верховенства права Ради Європи (ГД-I) щодо Закону «Про судоустрій і статус суддів» і внесення змін до Закону "Про Вищу раду юстиції», ухваленому Венеціанською комісією на їі 102-му пленарному засіданні (м. Венеція, 20-21 березня 2015 р.); (е) рішенні Європейського суду з прав людини у справі «Олександр Волков проти України» від 9 січня 2013 р. (заява № 21722/11) та інших.

По-друге, необхідно зберегти такий порядок формування їхнього складу, що забезпечує участь широкого кола суб'єктів у процесі, які представляють як найвищі органи держави (Парламент, Президента), так і суддівський корпус, прокурорів (статус яких поступово наближається до суддівського), адвокатів і науковців. 
Збереження зазначених векторів буде свідчити про європейський розвиток України і визнання основних демократичних стандартів у питаннях забезпечення діяльності органів судової влади.

\section{Jimepamypa}

1. Про судоустрій і статус суддів : Закон України від 2 червня 2016 р. № 1402-VIII. Oфiиiйний вicник України. 2016. № 56. С. 9. Ст. 1935.

2. Боровицький О.А. Суддівське врядування та суддівське самоврядування як гарантія незалежності судової влади. Університетські наукові записки. 2018. Т. 18. № 3 (71). С. 367-377.

3. Курганський О.В. До питання щодо суддівського врядування. Творчий шлях вченого: до 80-річчя професора В.В.Долежана / відп. ред. Н.М. Бакаянова. Одеса : Юридична література, 2018. С. 152-154.

4. Про вищу раду правосуддя : Закон України від 21 грудня 2016 p. № 1798-VIII. Офіційний вісник України. 2017. № 4. С. 180. Ст. 107.

5. Назаров I.В. Новий етап на шляху розвитку суддівського самоврядування в Україні. Юридична Україна. 2006. № 11. С. 83-86.

6. Долежан В.В. Юрисдикційна діяльність Вищої ради юстиції та шляхи ї̈ удосконалення. Наукові праці Національного університету «Одеська юридична академія» / голов. ред. С.В. Ківалов ; відп. за вип. В.М. Дрьомін. Одеса : Юрид. л-ра, 2012. Т. 11. С. 56-66.

\section{Анотація}

Сухарко А. В. Система органів суддівського врядування в Україні. - Стаття.

У статті йдеться про нормативне врегулювання порівняно нового для України інституту «суддівське врядування». Аналізуються норми законодавства, що стосуються визначення системи органів суддівського врядування та поняття зазначеного явища. Наводяться позиції науковців і практиків, які вже звертали увагу на зазначену проблематику. Зазначається, що важливим є розмежування суддівського врядування із суддівським самоврядуванням. Досліджуються нормативне врегулювання, завдання, система та компетенція органів суддівського самоврядування. Формулюються загальні риси органу суддівського врядування: (а) це державний орган, статус якого визначається Конституцією України або законом; (б) має статус юридичної особи і фінансується коштом державного бюджету; (в) працюе на постійній основі; (г) є колегіальним, незалежним органом у системі правосуддя; (г) до складу входять не лише професійні судді, а й представники інших правничих професій; (д) є відповідальним за забезпечення незалежності суддів, високопрофесійний склад суддівського корпусу.

Визначаються відмінності органів суддівського самоврядування від суддівського врядування: до їхнього складу входять виключно судді, йдеться саме про діючих суддів; поряд із завданням захисту незалежності суддів є завдання захисту професійних інтересів суддів, що виходить за межі і відрізняється від поняття незалежності; дуже часто робота суддівського самоврядування характеризується як участь у вирішенні питання, а не вирішення питання, тобто здебільшого суддівське самоврядування це обов'язковий елемент під час ухвалення рішення, але не суб'єкт його ухвалення.

Також у статті аналізуються міжнародні стандарти діяльності органів, подібних до вітчизняних Вищої ради правосуддя та Вищої кваліфікаційної комісії суддів України. Розглядаються варіанти оптимізації діяльності органів суддівського врядування, можливість їх об’єднання. Формулюються авторські висновки стосовно зазначеної проблематики. Зазначається, що необхідно зберегти такий порядок формування складу органів суддівського врядування, що забезпечує участь широкого кола суб์'єктів у процесі, які представляють як найвищі органи держави (Парламент, Президента), так і суддівський корпус, прокурорів (статус яких поступово наближається до суддівського), адвокатів і науковців.

Ключові слова: судова влада, суд, суддя, суддівське врядування, суддівське самоврядування. 


\section{Summary}

Sukharko A.V. The system of judicial governing bodies in Ukraine. - Article.

The article deals with the normative regulation of the institution of judicial governance, which is relatively new for Ukraine. The norms of the legislation related to the definition of the system of judicial governing bodies and the concept of this phenomenon are analyzed. The positions of scientists and practitioners who have already paid attention to this issue are given. It is noted that it is important to distinguish between judicial governance and judicial self-government. Accordingly, the normative regulation, tasks, system and competence of judicial self-government bodies are studied. The general features of bodies of judicial government, bodies of judicial self-government are formulated: (a) it is a state body whose status is determined by the Constitution of Ukraine or by law; (b) has the status of a legal entity and is financed from the state budget; (c) operates on a permanent basis; (d) is a collegial, independent body in the justice system; (e) be composed not only of professional judges but also of representatives of other legal professions; (f) is responsible for ensuring the independence of judges, highly professional members of the judiciary.

Differences between judicial self-government bodies and judicial governance are determined: they consist exclusively of judges and it is a question of acting judges; along with the task of protecting the independence of judges, there is the task of protecting the professional interests of judges, which goes beyond and differs from the concept of independence; very often the work of judicial self-government is characterized as participation in resolving the issue, rather than resolving the issue, i.e. in most cases judicial self-government is a mandatory element in decision-making, but not the subject of its adoption.

The article also analyzes the international standards of activity of bodies similar to domestic HCG and HQCYU. Options for optimizing the activities of judicial authorities, the possibility of combining them are considered. Author's conclusions concerning the specified problems are formulated.

It is noted that it is necessary to maintain such a procedure for forming the composition of judicial government, which ensures the participation of a wide range of entities in the process, representing both the highest state bodies (Parliament, President) and the judiciary, prosecutors (whose status is gradually approaching judicial).

Key words: judiciary, court, judge, judicial governance, judicial self-government. 